\title{
Wordsworth as a Critique of the Unfenced Societies
}

\author{
Faria Saeed Khan \\ University of Balochistan, Quetta, Pakistan.
}

\begin{abstract}
Nineteenth century was the Age of steam and iron. Charles Dickens was of the view that it was the best of the times and the worst of the times. Many writers and poets, in their works depicted the unforgettable memories and stories, of class prejudice, poverty, oppression, discontent and agitation of the newly created urban class. Wordsworth in his works critique the negative impact of the Industrial Revolution on the English society.

This research article will explore Wordsworth as a critique of the New World.
\end{abstract}

\section{Introduction}

The Industrial Revolution happened over a long period of time and the scale of change was massive. The English rural and urban community underwent great changes during the Industrial revolution. The traditional rural occupations and domestic industry was taken over by the factories. The agriculture ceased to dominate the economy of the State, as was done since time immemorial. Domestic trades were taken over by urban industry. The capitalists by using modern machinery to make economic progress, caused a disequilibria in society.

The living conditions of the farmers and the laborers became wretched because they lost their working opportunities. They could no longer rely upon small farms to maintain their living. Due to poverty they were forced to leave their native community and move to the industrial towns like London. In cities their lives became wretched as they were forced to alter their life style. The old sources of social wisdom lost public acceptability and people felt they had to find other ways of answering the questions thrown up by the modern world.

Wordsworth's experiences at Cambridge and London introduced him to the grim realities of the new world and challenged his idealistic view of life. Wordsworth was confronted and troubled by the negative effects of the time. His doctrine of nature is a campaign against the destruction of the individual by material and social pressures. He believed that nature is a source of reconciliation with life. It helps 'to regain that blessed mood in which the human mind irradiates and transforms the world.'(http://facta.junis.ni.ac.yu/lal/lal97/lal9702.pdf)1

Wordsworth joined Cambridge at the age of seventeen. Cambridge led him into artificial life and diverted his attention from the simple and profound virtues of his old mountain life. At first Wordsworth's sight was dazzled by the novel show of the university environment and activities. 'He was elated, proud and happy, and felt to be 'a man of business.'(Sarker,2001:495)2 Soon Wordsworth realized that 'I was not for that hour/ Nor for that place' because he was able to see the darker side to the picture. At one place he shares with his friend, De Quincey that 'the manner of the young men were very frantic...'(Selincourt,1959:1X1V)3 The relations between town-and-gown was extremely hostile. The streets were unpaved and very dark at night because illuminations were reserved for special occasions only. Cambridge had two kinds of students: reading and non reading. Most students were non reading men. Academic work was not important for most of the Cambridge students. They were more interested in parties and supper parties. According to Johnston, 'Students met, boasted, argued, and quarreled in the taverns with each other or with the town 'snobs'....between the students and the town boys, the fights were very frequent and very violent..' (Johnston,1998:126-127-129)4

Cambridge divided the students in three categories: nobles, pensioners, and sizars. Being an orphan Wordsworth was dependent on his guardians for educational loans. Therefore, in the college, he was given the rank of sizar. This was the lowest category. The sizars were looked down upon. They were expected to distinguish themselves by hard work and success. Even at dinner the sizars were not allowed to join the nobles. They sat with the pensioners. Their food was sometimes made up from the leftover of the high tables. Wordsworth had to wear splendid clothes as good as any of the lords who were his classmates. In Book 3 Wordsworth says:

I had made a change

In climate; and my nature's outward coat

Changed also, slowly and insensibly.

To the deep quiet and majestic thoughts 
Of loneliness succeeded empty noise

And superficial pastimes; ... (209-214)

Initially Wordsworth tried to reconcile with the mood of the institution but neither the university nor the manners of the student life provided social environment that suited his idea of humanity or brotherhood, rather it instilled in his mind a vain disregard for common man.

Call back, O Friend! A moment to thy mind,

The place itself and fashion of the rites.

Up-shouldering in a dislocated lump

With shallow ostentatious carelessness,

My Surplice, gloried in, and yet despised,

I clove in pride through the inferior throng

Of the plain Burghers, who in audience stood

On the last skirts of their permitted ground,

Beneath the pealing Organ. Empty thoughts!

I am ashamed of that great Bard,

And thou, O Friend! who in thy ample mind

Hast station'd me for reverence and love,

Ye will forgive the weakness of that hour

In some of its unworthy vanities,

Brother of many more. (3,312-326)

The class prejudice and the superior attitude which Wordsworth talks about is discernible in the description of his urban college mates, whom he imagines to be standing on the last skirts of their specified zone as if they longed to enter the student's space but were forbidden to do so by their lower rank. The institution made Wordsworth cognize the fact that society has parted man from man by outside marks and has neglected ' the universal heart.' (12.218) Pinion says: He knew ' How books debase the many for the sake of the wealthy few' who see by artificial lights, and how they set forth 'extrinsic differences and neglect the universal heart.' (Pinion, 1984:150)5

In such an environment, Wordsworth tried hard not to lose faith in humanity. Selincourt says, ' there could hardly be stronger testimony to the soundness of his early education and the strength of his character than that he could pass unscratched through the Cambridge of his day.'(Selincourt,lxiv)6 Wordsworth started avoiding the social activities of Cambridge. Although he was not averse to company of men, yet there was a niche within his soul that would not get stirred by gangs of companions. He felt restricted and unfulfilled at university because he thought that he had a vocation other than academic work. He says:

Oft did I leave

My Comrades, and the Crowd, Buildings and Groves,

And walked along the fields, the level fields, (91-93)

Unlike the 'loyal students faithful to their books,' who aspired academic glories, Wordsworth would wander across the fields and searched for universal things. As Dr Aleris Carrel rightly said, 'The born criminal...... does not exist.....there are born defectives...their moral sense has not developed. This disharmony in the world of consciousness is a phenomenon characteristic of our time. We have succeeded in giving organic health to the inhabitants of the modern city. But despite the immense sum spent on education, we have failed to develop completely their intellectual and moral activities....The happiest and most useful men consist of a well integrated whole of intellectual, moral, and organic activities ....It is only with such thoroughly developed individuals that a real civilization can be constructed.'(Carrel,137)7

London brought Wordsworth into close contact with the oppressive realities of society, ' ...... all those loathsome sights/ Of wretchedness and vice;'(73-74) . In The Prelude London is a corrupt city which is dominated by the law of profit and gain. In his poem London, Wordsworth depicts the city as a 'fen of stagnant waters' and its people as selfish men. In the Capital, social institutions are corrupt. Majority of the respectable leaders of society are hypocrite. People live artificial life. Wordsworth considered them as entertainers:

Pass we from entertainments that are such

Professedly to others titled higher,

Yet in the estimate of youth at least,

More near akin to these than names imply,

I mean the brawls of Lawyers in their Courts 
Before the ermined Judge, or that great Stage

Where Senartors, tongue-favor'd Men, perform,

Admir'd and envied.... (-486 - 493)

Life became deceptive. Honesty and sincerity disappeared from the city, even from the religious institutions. In

The Prelude Wordsworth satirically describes a preacher and says:

.. $\quad$......... and where but in the holy Church?

There have I seen a comely Bachelor,

Fresh from a toilette of two hours, ascend

The Pulpit, serapic glance look up,

And in a tone elaborately low

Beginning, lead his voice through many a maze,

A minuet course, and winding up his mouth,

From time to time into an orifice

Most delicate, a lurking eyelet, small

And only not visible, again

Open it out, diffusing thence a smile

Of rapt irradication exquisite. (513-560)

Men turned into machines. Sarker is of the view that Wordsworth's 'most painful and shattering experience in London was that people did not feel the necessity of communicating among themselves, and each one of them lived in a sort of cocoon created by himself.'(Sarker, 2003:521)8 Urban life was compartmentalized and man was parted from man. Even the next door neighbours were strangers to each other. In Book 7 Wordsworth says:

......Above all, one thought

Baffled my understanding, how men lived

Even next-door neighbours, as we say, yet still

Strangers, and knowing not each other's names. (115-118)

In Book 12 Wordsworth says:

Love cannot be ;nor does it thrive with ease

Among the close and over crowded haunts

Of cities, where human heart is sick,

And the eye feeds it not, and cannot feed.(202-205)

Wordsworth says that in London men were deprived of their true identity. According to Sarker says, Wordsworth saw and noted 'all specimens of man, and studied men of diverse personages and characters, of many nations'. (Sarker,2001:518)9 Wordsworth observed that London was disintegrated and people were known and remembered by their superficial distinctions. Wordsworth says:

Among the crowd, conspicuous less or more,

As we proceed, all specimens of Man

Through all the colours which the sun bestows,

And every character of form and face,

The Swede, the Russian; from the genial South,

The Frenchman and the Spaniard; from remote

America, the Hunter- Indian; Moors,

Malays, Lascars, the Tartar and Chinese,

And Negro Ladies in white muslin gowns. (221-228)

In London of 1770 there was plenty of poverty and degradation. Poor people were unable to help themselves they had to adopt any means, even shows, quackeries, or prostitution to fill their bellies. The beggars in the streets pretended in -order to receive donations, because being crippled was not sufficient. The beggar had to turn his face towards the passer by in order to appeal to his compassion. Prostitution was common. When Wordsworth saw a prostitute in the streets he was not seduced by her rather he felt pity for her and thought about the inhumanness of man. According to Johnston, '...that every tenth woman Wordsworth saw was likely to be a prostitute.....'(Johnston,1998:224)10 Once while Wordsworth and his friend Nicholson were returning home, they saw a prostitute and Wordsworth started 'wondering about his pious companionand himself- neither of whom looks at or says anything to the unhappy women.'(ibid)11 He feels pity for the woman and blames society for her condition.

In London, like the other towns of England, population increased due to the migration of farmers. The Londoners were forced to live in pathetic conditions due to over population. According to Purkis's statement: 
'the cheap housing, poor diet, and squalid surroundings produced a total environment that had a depressing effect upon human endeavour......... To some observers, the new generation who were born into this environment appeared stunned and uncouth; their cheap clothing, and strange variation on the English language made them seem like another species, almost subhuman..' (Purkis,1988:49)12 In Preface to the Lyrical Ballads, Wordsworth deplores 'the increasing accumulation of men in cities.'( Cited inOwen,1974:73)13 In The Prelude Wordsworth says:

Oh, blank confusion! and a type not false

Of what the mighty City is itself

To all except a Straggler here and there,

To the whole Swarm of its inhabitants;

An undistinguishable world to men,

The slaves un respited of low pursuits,

Lying amid the same perpectual flow

Of trivial objects, melted and reduced

To one identity,... (721-727)

According to Michael, 'When Wordsworth was born, approximately $25 \%$ of the population lived in cities; by the time he died, this had doubled, and the population overall almost-tripled in the course of the 18th century.'(Flinn.Michael, British Population Growth, 1700-1850,London:Macmillan,1790)14 But still the Londoners lived a lonely life. The rush and the roar of city life lessened the possibility of socializing. They lived a life of fiction and wanted an escape from the realities of life. According to Blank, 'The urban living conditions and uniformity of occupation constitutes the condition for the demise of high culture and loss of discriminating powers in a society that seeks escapism in a craving for sensational entertainment.'(Blank, The Journal of Popular Culture.Vol 39.No3,2006,Blackwell Publishing, Inc: P.365)15 Absorbed in the hustle and bustle they had no time to establish bonds of affection among themselves. Wordsworth describes the chaos of London city in the following lines:

The broad high-way appearance, as it strikes

On Strangers of all ages, the quick dance

Of colours, lights and forms, the Babel din

The endless stream of men, and moving things, (153-156)

The city appeared as an 'endless stream of moving men and moving things'(156) According to Averill, ' Book V11's concluding image, freak-show at Bartholomew Fair, is synecdoche of London's 'blank confusion'. (Averill,1980:261)16 In The Prelude, Wordsworth recalls the crowd, the din, and the darkness of the congested streets and the impression of shops on him. He says:

Here and there and everywhere a weary Throng

The Comers and the Goers face to face,

Face after face; the string of dazzling Wares,

Shop after shop, with Symbols, blazon'd Names, (155-158)

The city gave the impression of a tumult. The chaos of urban environment translated into social alienation, as life was reduced to a dull routine.

London had no sympathy or compassion for Man, and no respect for old traditions or for the moral values. When Wordsworth's poems were criticized by Londoners he said, '..they are altogether incompetent judges. These people in the senseless hurry of their idle lives do not read books, they mere snatch a glance at them that they may talk about them...for this multitude of unhappy, and misguided, and misguiding beings, an entire regeneration must be produced;....'( Cited in Owen,1974:115)17

Londoners were being swallowed and absorbed by the trivialities of life. They were gradually shifting away from the realities and the essence of life. Watson says that Wordsworth, '...experienced (during his stay in London) the sudden transition from a moral and agriculture society to a 'mass society'; ......experience of London gave him an insight into these problems, and a life long attachment to the value which the mass society denied: individuality, local loyalty, the spirit of community.'( Watson,1992:166)18 In The Prelude Wordsworth says:

The slaves unrespited of low pursuits, (724)

Living amid the same perpetual flow

Of trivial objects, melted and reduced 
To one identity, by differences

That have no law, no meaning, and no end;

Oppression under which even highest minds

Must labour, whence the strongest are not free

Wordsworth walks away from the city of bondage: a city which is dominated by a crowd that apes the reality. Wordsworth says:

A farewell to the City left behind,

I journey'd towards the Vale that I had chosen. (98-100)

Wordsworth left London to inhale life and to respond to it. He says:

$\mathrm{OH}$ there is a blessing in this gentle breeze

That grows from the green fields and from the clouds

And from the sky: it beats against my cheeks,

And seems half conscious of the joy it gives.

$\mathrm{O}$ welcome Messenger! O welcome Friend!

A captive greet thee, coming from a house

Of bondage, from yon City's walls set free,

A prison where he hath been long immured

Now I am free, enfranchis'd and at large,

May fix my habitation where I will. (1-9)

Being brought up in an intimate and a free society of Cockermouth, the poet prefers a society which is 'less under restraint....less under the influence of social vanity' (Owen,1974:71)19 In Book X1 he says:

For, born in a poor District, and which yet

Retaineth more of ancient homeliness,

Manners erect, and frank simplicity,

Than any other nook of Englisn Land. (215-218)

Wordsworth thought that all human beings are dignified; whether rich or poor because they are essentially the same. He idealized a community in which all institutions would enhance personal freedom. Where man is not turned into a machine but is humanized by the society. Thus urban societies were superseded by the poet. He saw hope in simple pursuits of life. Wordsworth decides to return to his native land.

\section{Conclusion}

The harmful effects of the unruly societies represented by Cambridge and London introduced Wordsworth to the gloomy side of the picture. He wondered why there are so few examples of virtuous people. But Wordsworth never escaped from the bitter realities of life. He recollected his past experiences of simple rustic life. The memories of his past revitalized him and enabled him to maintain his optimism. Wordsworth returns to the Lake District. He returns to his meek men, gentle English folks whose activities were aroused not by the pompous names of power and action but by display of love and fellow feeling. Such display of love and affection kindled in Wordsworth his faith in humanity.

[1] http://facta.junis.ni.ac.yu/lal/la197/la197-02.pdf

\section{References}

[2] Sunil Kumar arker, A Companion To William Wordsworth :Vol 2 ( Atlantic Publishers:2003),495

[3] Earnest De. Selincourt,ed; Wordsworth, The Prelude (London: Oxford University Press: 1965),1X1V

[4] Kenneth R.Johnston, The Hidden Wordsworth: Poet.Lover.Rebel.Spy,( New York:W.W.Norton\& Company, Inc:1998),126-127-129

[5] F. B Pinion, AWordsworth Champion, (London, The Macmillian Press Ltd:1984),150

[6] Earnest De. Selincourt,ed; Wordsworth, The Prelude (London: Oxford University Press: 1965),1X1V

[7] Sayyid Mujtaba Musawi Lari,qtd;Carrel, Ethics and Spiritual Growth,(Iran: Foundation of Islamic Cultural Propagation in the World:1997)1370

[8] Sunil Kumar Sarker, A Companion To William Wordsworth : Vol 2 ( Atlantic Publishers:2003), 510 ibid,518

[9] Kenneth R.Johnston, The Hidden Wordsworth: Poet.Lover.Rebel.Spy,( New York:W.W.Norton\& Company, Inc:1998),224 ibid

[10] John Purkis: Wordsworth, ( India:Pearson Education Ltd:2003)49

[11] J.W.B.Owen,ed;Wordsworth,Wordsworth'sLiteraryCriticism(London:Routeledge\&Kegan Paul Ltd: 1974), 73

[12] Flinn.Michael, British Population Growth, 1700-1850(London:Macmillan:1790)

[13] Blank, The Journal of Popular Culture.Vol 39.No3,2006,Blackwell Publishing, Inc: P.365

[14] James H. Averill, Wordsworth and the Poetry of Human Suffering, (London:Cornell University Press:1980), 261

[15] W.B.Owen,ed;Wordsworth,Wordsworth,Wordsworth'sLiteraryCriticism (London:Routeledge\&Kegan Paul Ltd: 1974), 115

[16] J.R.Watson, English Poetry of the Romantic Period:1889-1830.2nd ed( London and New York: Longman Publishing:1992)166

[17] W.B.Owen, ed;Wordsworth,Wordsworth,Wordsworth'sLiteraryCriticism (London:Routeledge\&Kegan Paul Ltd: 1974),71 